\title{
Producing renewable electric energy through a microbial fuel cell in the rice field
}

\author{
HADI WISA NUGRAHA, GUNAWAN DJAJAKIRANA, SYAIFUL ANWAR, DWI ANDREAS SANTOSA \\ Department of Soil Science and Land Resource, Faculty of Agriculture, Institut Pertanian Bogor. Jl. Meranti, Bogor 16680, West Java, Indonesia. \\ Tel.: +62-251-8629354, Fax.: +62-251-8629352, ‘email: dsantosa@indo.net.id
}

Manuscript received: 6 July 2020. Revision accepted: 15 August 2020.

\begin{abstract}
Nugraha HW, Djajakirana G, Anwar S, Santosa DA. 2020. Producing renewable electric energy through a microbial fuel cell in the rice field. Biodiversitas 21: 4139-4146. Microbial Fuel Cell (MFC) is an alternative technology that converts chemical energy into electrical energy using microbes. This study aimed to apply MFC technology in the rice field to produce renewable electricity by utilizing microbes that have been previously isolated. The study was conducted in two experiments. The first experiment was carried out to select MFC prototypes with different in the oxygen circulation system (anode and cathode holes) that capable of producing the highest Voltage. The second experiment was performed to test the selected MFC prototype for electricity production in 12 combination treatments of microbes, organic matter, and fertilization (mixed NPK fertilizer) with three replications on rice cultivation in a greenhouse. The results showed that the best MFC prototype was a prototype that has two holes, each at anode and cathode (MFC 2). The highest electrical Voltage was generated by the treatment with microbes and organic matter, without fertilizer. The treatments produced the highest electrical current was the addition of microbes, organic matter, without and with $50 \%$ fertilizer. The highest power density was generated by the treatment with microbes and organic matter, without fertilization. The addition of ex-situ isolated microbes significantly increased the production of electricity.
\end{abstract}

Keywords: Fertilizer, isolated microbes, MFC prototype, organic matter, renewable energy

\section{INTRODUCTION}

Research on the utilization of biological energy as renewable energy has attracted a lot of attention. Microbial Fuel Cell (MFC) is an alternative technology that converts chemical energy into electrical energy using microbes as a catalyst. It can produce renewable energy from waste, so it is good to be developed (Kumar et al. 2016). The commonly used MFC is a dual-chamber which has cathode and anode chambers as the main components. Between the cathode and the anode, there is a proton exchange membrane (PEM) that can be passed by small ions so that protons produced at the anode can pass through the membrane and transferred to the cathode (Logan et al. 2005). At the anode section, microbes groups break down nutrients or substrates (organic matter) in the surrounding medium and produce highly reduced biomolecules through natural metabolic pathways. Microbes provide their electrons through one mechanism out of three electron transfer mechanisms, i.e., direct transfer from the cell wall of microbes, utilizing secondary biomolecules, and electron transfer via nanowires (Lovley and Nevin 2008). Types of electron acceptors in the cathode section determine the performance of the MFC system (Fan and Xue 2016). Therefore, substrates from different organic matter produce different electrical energy.

The principle of MFC is determined by the processes that occur in the anode and cathode chambers. The rate of substrate conversion by microbes and the rate of electron transfer from the microbes to the electrode surface is a process that occurs in the anode chamber and affects the performance of the MFC system. The added organic matter has the potential as a source of substrate for microbes in the MFC system. Several organic matters that can be used as substrates in MFC are glucose (Liu et al. 2004), starch (Min et al. 2005), fatty acids (Liu et al. 2005), amino acids and proteins (Logan et al. 2005), as well as wastewater from humans and animals (Liu et al. 2004).

There are various types of MFCs, namely MFC single chamber, MFC double chamber, MFC stacked, and MFC upflow. MFC single chamber is an MFC consisting of a single chamber containing a cathode and anode. MFC dual chamber is the simplest type of design. This MFC uses a chamber with a different shape used as an anode and another chamber used as a cathode. The proton exchange membrane separates cathode and anode chambers. Stacked MFC is a combination of several MFCs that are combined in series or in parallel to increase electric power (Sun et al. 2012). MFC upflow is the latest of MFC design following MFC research developments. MFC upflow is a cylindrical MFC (He et al. 2006).

The richness of Indonesia's biodiversity (microbes and ecosystems) is one of the great opportunities for the development of MFC technology. This technology can be applied in the rice fields that are always flooded due to the anaerobic condition. This study was carried out in the rice field to test the MFC prototype and to determine the best treatment (microbes, organic matter, and fertilization) in producing electrical energy. 


\section{MATERIALS AND METHODS}

\section{Producing and selecting the MFC prototypes} Producing an MFC prototypes

The initial stage of this study is to build a prototype of MFC chambers. In this study, three types of MFC prototypes were made using PVC pipes. The first type (Figure 1.A) is an MFC prototype that has a square-shaped hole in the middle of the pipe. The second type (Figure 1.B) is an MFC prototype that has square-shaped holes at the top and bottom of the pipe. The third type (Figure 1.C) is an MFC prototype that has a small round hole and many holes in the middle of the pipe (patent number
P00201806329). In the anode and cathode section, a carbon fiber size of $10 \mathrm{~cm} \times 10 \mathrm{~cm}$ was placed and used as an electrode.

\section{Prototype selection and testing}

The MFC prototype testing was carried out in the rice field in Bogor, West Java, Indonesia (Figure 2.A), for 98 days following the growing period of paddy. The parameters measured are the Voltage (Figure 2.B) and the electric current. Prototype producing the highest Voltage used for further research in the greenhouse to determine doses of microbes, organic matter, and fertilizer.

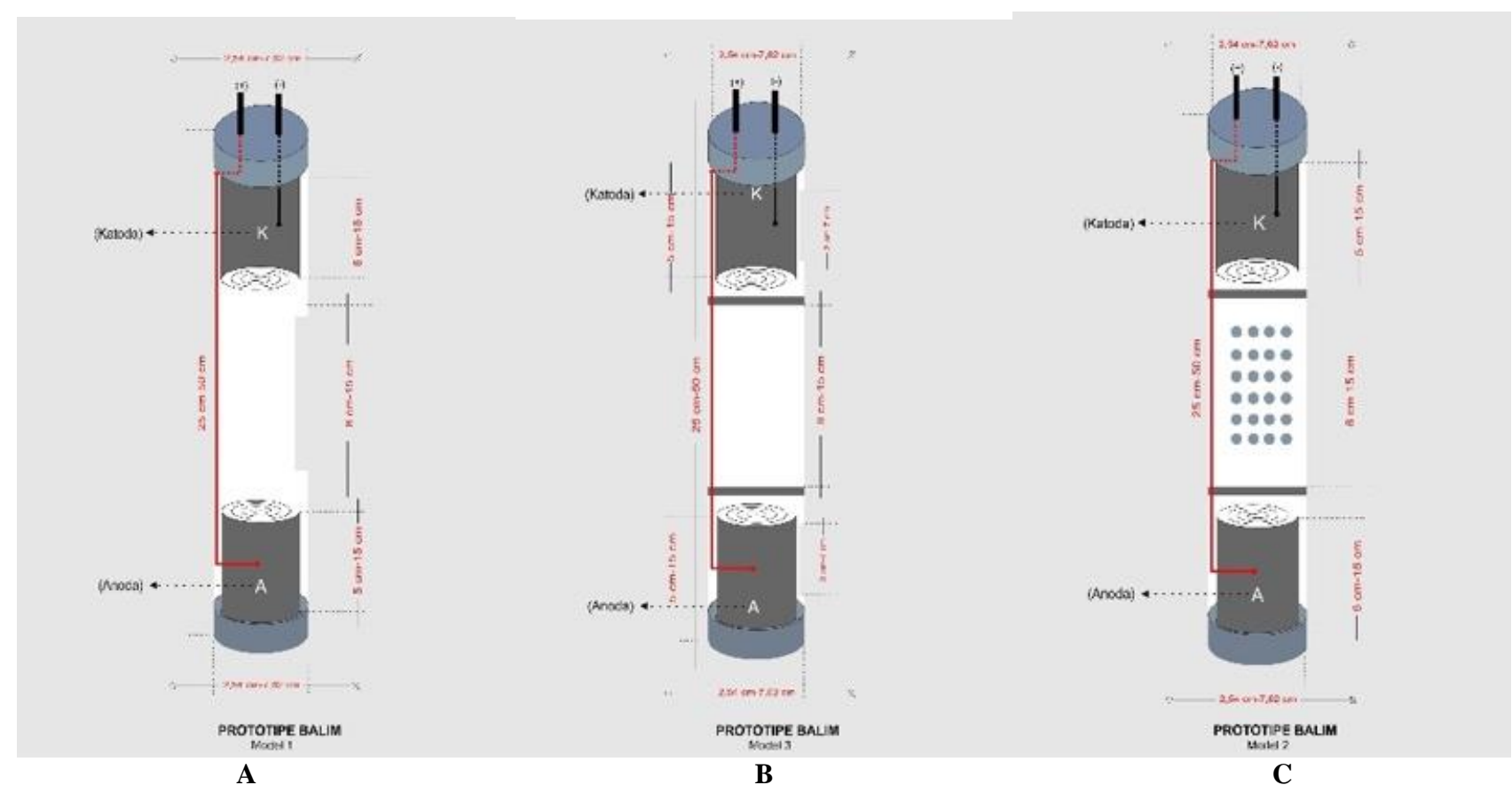

Figure 1. MFC protoype 1 (A), 2 (B), 3 (C)

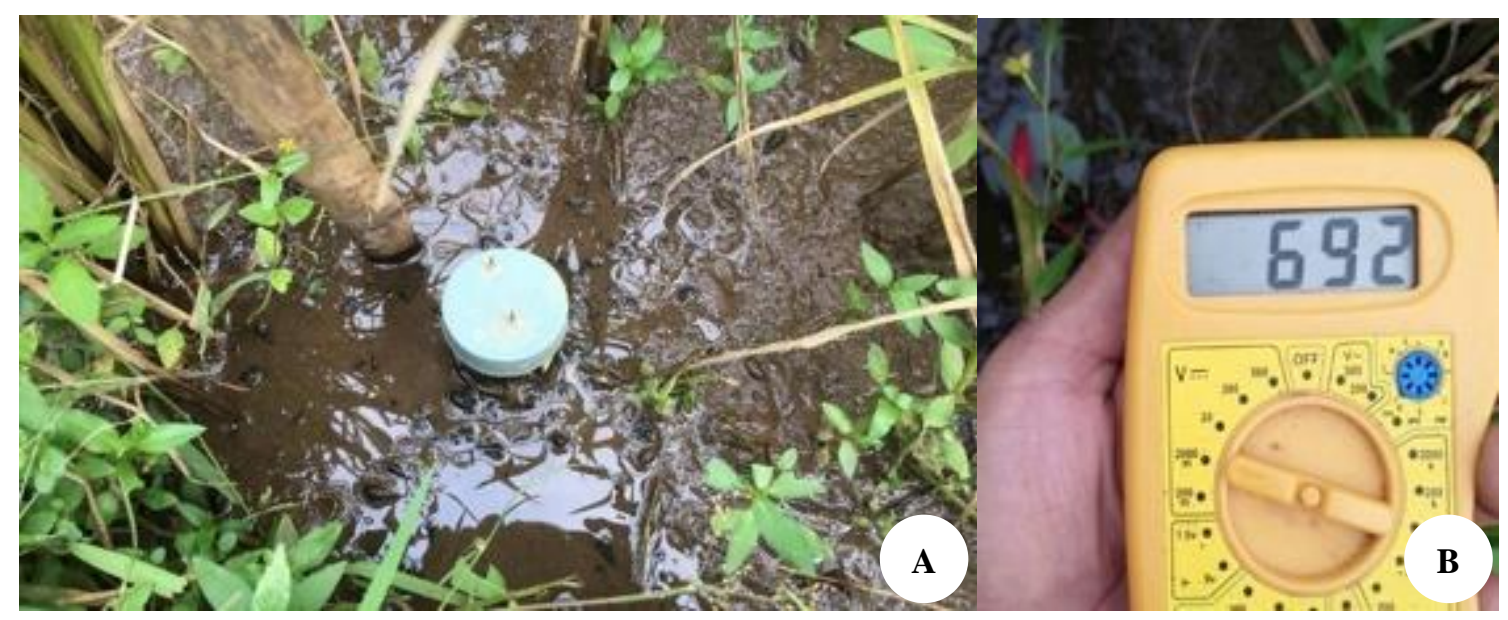

Figure 2. A. MFC prototype in the rice field, B. Measurement of electric Voltage on MFC using the multiparameter tool 


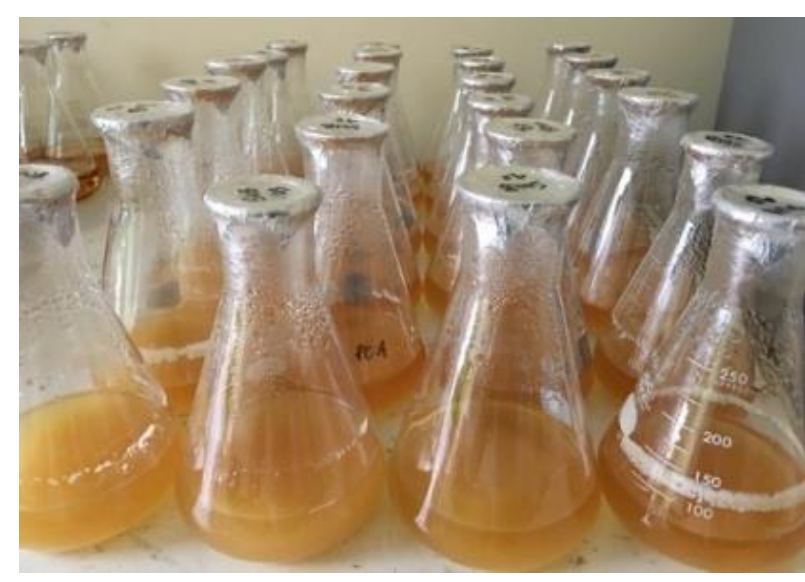

Figure 3. Growth media for microbial propagation

The effect of treatments (microbes, organic matter, and fertilization) on electrical energy produced Microbial propagation

Microbial isolate used in this study are bacteria that can provide the highest Voltage and electrical power and have the potential for MFC, i.e., Staphylococcus saprophyticus (Indriyani 2017) This isolate was collected from the rice field in Banten. Microbial propagation is carried out in a laboratory using prepared media (Figure 3). The media contains $50 \mathrm{ml}$ of Staphylococcus saprophyticus bacterial suspension (Optical Density 0.5) and $400 \mathrm{ml}$ of $0.1 \mathrm{M}$ glucose solution and $0.1 \mathrm{M}$ phosphate buffer solution $\mathrm{pH} \pm$ 7.0 (Min et al. 2008). The cathode compartment was immersed in $400 \mathrm{ml}$ of $0.01 \mathrm{M}$ potassium permanganate solution and $0.1 \mathrm{M}$ phosphate buffer $\mathrm{pH} \pm 7.0$. (GuerreroRanger 2010).

\section{Anode and cathode compartment on the MFC prototype}

The anode compartment was immersed in $50 \mathrm{~mL}$ bacterial suspension with Optical Density 0.5 and $400 \mathrm{~mL}$ of $0.1 \mathrm{M}$ glucose solution and $0.1 \mathrm{M}$ phosphate buffer solution $\mathrm{pH} \pm 7.0$ (Min et al. 2008). The cathode compartment was immersed in $400 \mathrm{~mL}$ of $0.01 \mathrm{M}$ potassium permanganate solution and $0.1 \mathrm{M}$ phosphate buffer $\mathrm{pH} \pm 7.0$ (Guerrero-Ranger 2010).

\section{Planting preparation and cultivation}

Soil for planting in pots originated from land that is considered homogeneous and has been routinely planted with paddy rice for years. The remaining straw is sprayed with decomposer Provibio ${ }^{\circledR}$ for the decomposition process in the field. A variety of paddy used in this study is the new high-yielding IF8 (Indonesian Farmer 8) that has been bred by local farmers in Karanganyar, Central Java, Indonesia. Seeds are sown and prepared for transplantation. Fourteenday-old rice was planted in pots (Figure 4). Soil media that has been homogenized with composted remaining straw was used as planting media in the pots. Rice seeds were planted in pots containing treated soil (treated with/without the addition of microbes, organic matter, and fertilizer). The electrical voltage and electrical current in the pots were measured using the MFC prototype.

\section{Experimental design}

This study used a factorial completely randomized design with 12 treatments, i.e., the combination of the addition of microbes (M0: without and M1: with microbes), organic matter (BO0: without and BO1: with organic matter), and fertilizer (K0: without, K1: $50 \%$ fertilizer, and K2: $100 \%$ fertilizer). The fertilizer dosage used in each pot was 32 grams of organic matter, and NPK fertilizer (Urea, SP-36, and $\mathrm{KCl}$ ). Dosage of NPK fertilizer in each pot for K1 was Urea (1.6 gram), SP-36 (0.8 gram), and $\mathrm{KCl}$ (0.8 gram), while $\mathrm{K} 2$ treatment consisted of Urea (3.2 gram), SP-36 (1.6 gram), and $\mathrm{KCl}$ (1.6 gram).

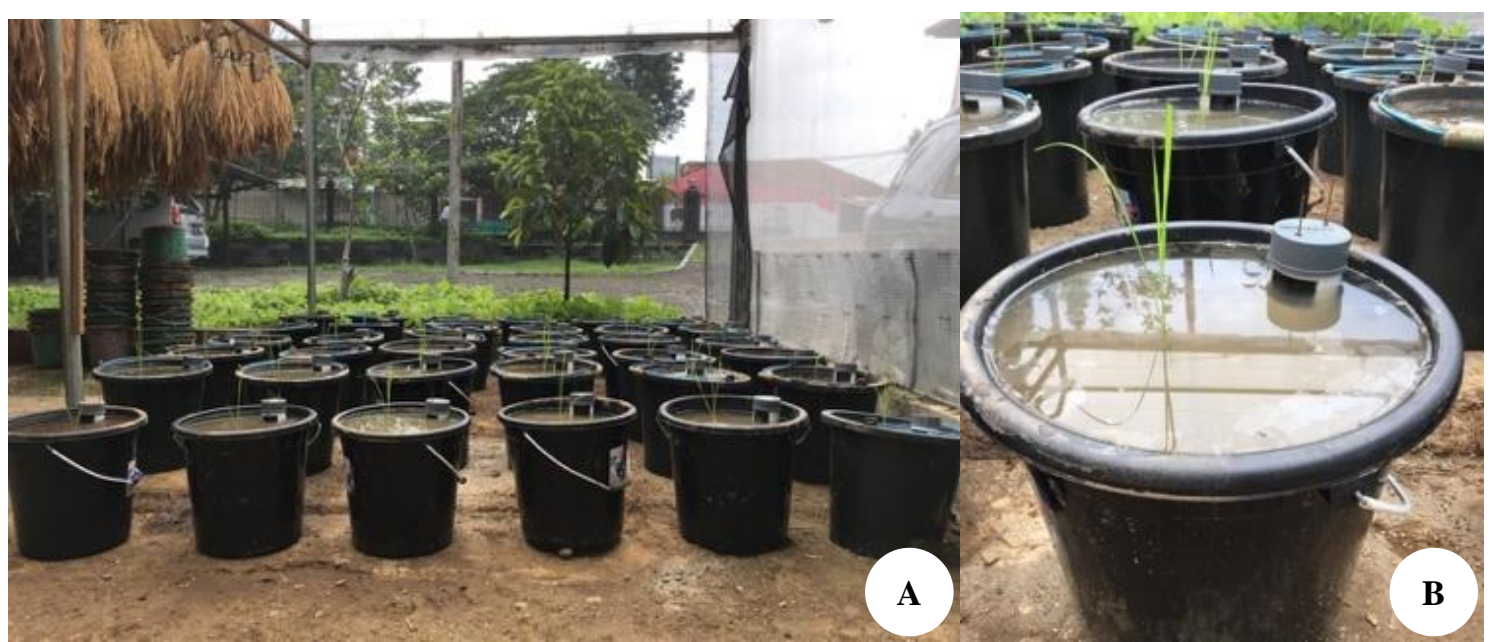

Figure 4. MFC in cultivation pots 
Measurement of electrical energy

Measurements of electrical energy include measurements of current (I) and Voltage (V) so that the amount of power or power density $(\mathrm{P})$ in an electric circuit could be calculated. Electrical power measurement results in units per square meter for 1 unit of MFC. Measurements were made in each pot of the experiment with three replications using a digital multimeter brand UNI-T type UT $33 \mathrm{~B}+$ to obtain the average current and voltage produced.

$$
\text { Power density }\left(\frac{W}{m^{2}}\right)=\frac{\text { Voltage }(V) x \text { Ampere }(I)}{\text { Surface area } \operatorname{MFC}\left(m^{2}\right)}
$$

\section{Data analysis}

Electric Voltage, electric current, and power density generated in each pot of the experiment were observed. Data were processed using Microsoft Excel. The data were analyzed using analysis of variance (ANOVA), if there were significant differences among treatments, then the data analysis was continued with DMRT (Duncan Multiple Range Test) on the level of $95 \%$.

\section{RESULTS AND DISCUSSION}

\section{Selecting the best MFC prototype}

The electrical energy produced by three types of prototypes in the rice field was presented in Table 1. MFC prototype number 2 (MFC prototype that has squareshaped holes at the top and bottom of the pipe) produces the highest electrical Voltage and electrical current. Therefore it is used for further study in the greenhouse to determine the optimal dose of microbes, organic matter, and fertilizer.

\section{Selecting the best treatment for producing electrical energy}

\section{Electric voltage of $M F C$}

The results (Figure 5) showed that treatment with microbes and organic matter without fertilizer produced the highest electrical Voltage $(555 \pm 34.80 \mathrm{mV})$.

Table 2 showed that the addition of microbes and organic matter has a significant effect on electrical Voltage. The results of DMRT showed that the addition of microbes significantly increase the electric Voltage (Table 3), while the addition of organic matter also increases the electrical Voltage significantly (Table 4)

The electric current of MFC

The results (Figure 6) showed that the highest electrical current $(1.63 \pm 0.03 \mu \mathrm{A})$ was obtained from the treatments of microbes addition, organic matter, without and with $50 \%$ fertilizer.

\section{The electric current of $M F C$}

The results (Figure 6) showed that the highest electrical current $(1.63 \pm 0.03 \mu \mathrm{A})$ was obtained from the treatments of microbes addition, organic matter, without and with $50 \%$ fertilizer.

Table 1. Electric Voltage and electric current produced by MFC prototype

\begin{tabular}{ccc}
\hline \multirow{2}{*}{ MFC Prototype } & \multicolumn{2}{c}{ Average* } \\
\cline { 2 - 3 } & Voltage $(\mathbf{m V})$ & Current $(\mathbf{m A})$ \\
\hline 1 & 147 & 57 \\
2 & 718 & 140 \\
3 & 336 & 72 \\
\hline
\end{tabular}

Note: *an average electrical voltage and electrical current for 98 days observation

Table 3. The effect of microbes addition on electric Voltage

\begin{tabular}{cc}
\hline Microbes & Electric Voltage $(\mathbf{m V})$ \\
\hline M0 & $240.08 \pm 27.18 \mathrm{~b}$ \\
M1 & $501.71 \pm 50.25 \mathrm{a}$ \\
\hline
\end{tabular}

Note: Values followed by a similar letter in the same column are significantly differed according to Duncan Multiple Range Test at $5 \%$ level

Table 4. The effect of organic matter addition on electric Voltage

\begin{tabular}{cc}
\hline Organic Matter & Electric Voltage $(\mathbf{m V})$ \\
\hline BO0 & $342.69 \pm 135.6 \mathrm{~b}$ \\
BO1 & $399.1 \pm 139.4 \mathrm{a}$ \\
\hline
\end{tabular}

Note: Values followed by a similar letter in the same column are significantly differed according to Duncan Multiple Range Test at $5 \%$ level

Table 2. The effect of treatment on electric voltage

\begin{tabular}{|c|c|c|c|c|c|c|}
\hline $\mathbf{P}$ & Factor & SS & $\mathbf{V}$ & MS & $\mathbf{F}$ & Sig \\
\hline \multirow{7}{*}{$\begin{array}{l}\text { Electric } \\
\text { voltage }\end{array}$} & Microbes & 616077.77 & 1 & 616077.77 & 664.44 & $<0.000^{*}$ \\
\hline & Organic matter & 28637.791 & 1 & 28637.791 & 30.886 & $<0.000 *$ \\
\hline & Fertilizer & 151.661 & 2 & 75.831 & 0.082 & $0.922 * *$ \\
\hline & Int $1(\mathrm{M} * \mathrm{BO})$ & 287.732 & 1 & 287.732 & 0.310 & $0.583 * *$ \\
\hline & Int $2\left(\mathrm{M}^{*} \mathrm{~K}\right)$ & 282.629 & 2 & 141.315 & 0.152 & $0.859 * *$ \\
\hline & Int $3\left(\mathrm{BO}^{*} \mathrm{~K}\right)$ & 1216.404 & 2 & 608.202 & 0.656 & $0.528 * *$ \\
\hline & Int $4\left(\mathrm{M}^{*} \mathrm{BO} * \mathrm{~K}\right)$ & 2657.029 & 2 & 1328.515 & 1.433 & $0.258 * *$ \\
\hline
\end{tabular}

Note: *significant difference 


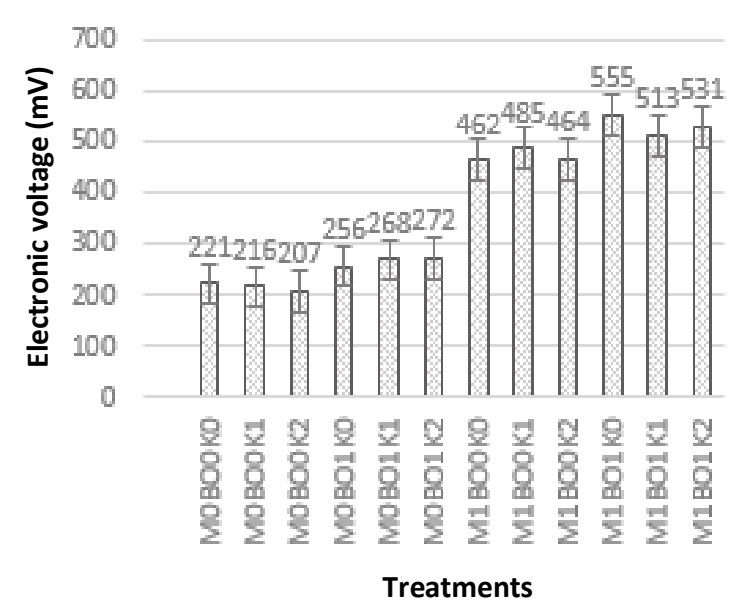

Figure 5. Electric voltage produced by treatment of microbe (M0: without and $\mathrm{M} 1$ : with microbe), organic matter (BO0: without and BO1: with organic matter), and fertilizer (K0: without, K1: 50\% fertilizer, and K2: $100 \%$ fertilizer)

Table 5 showed that electric current was significantly affected by the addition of microbes, organic matter, and fertilizer application. Interactions between microbes, organic matter, and fertilizer result in significantly different electric currents (Table 6). Treatments of microbes and organic matter without fertilizer and $100 \%$ fertilizer affected significantly on electric current.

\section{The power density of MFC}

The highest average power density $(0.09 \pm 0.011$ $\mathrm{mW} / \mathrm{m}^{2}$ ) was obtained from the treatment of the addition of microbes and organic matter, without fertilization (Figure 7). The results showed that the treatment of fertilizer application with recommended doses $(100 \%)$ reduced power density. Power density from treatment with 50\% fertilizer and $100 \%$ fertilizer were $0.09 \pm 0.001 \mathrm{~mW} / \mathrm{m}^{2}$ and $0.06 \pm 0.002 \mathrm{~mW} / \mathrm{m}^{2}$, respectively. Microbes addition and organic matter results in significantly different power density. Treatments without microbes, organic matter, and fertilizers (M0BO0K0) produce the lowest power density.

Table 7 showed that microbes, organic matter, and fertilizer affected power density significantly. There are

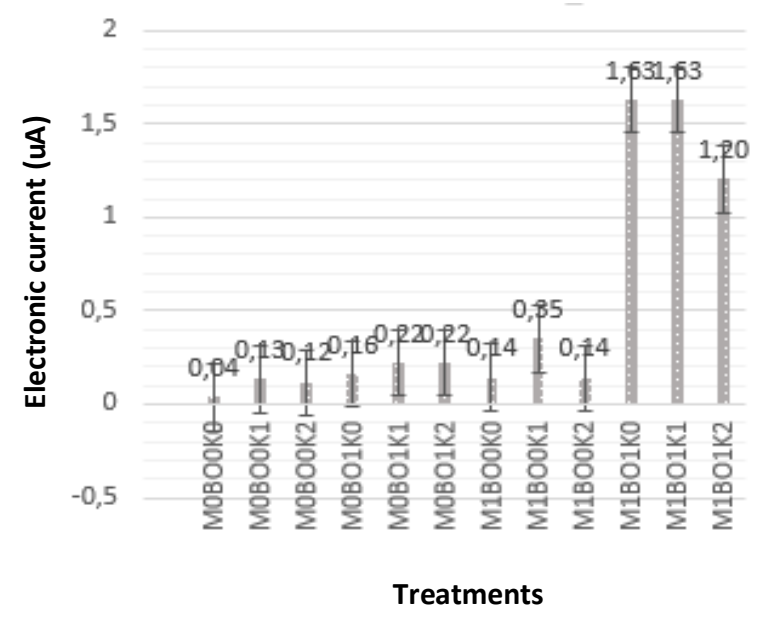

Figure 6. Electric current produced by treatment of microbe (M0: without and M1: with microbe), organic matter (BO0: without and BO1: with organic matter), and fertilizer (K0: without, K1: 50\% fertilizer, and K2: $100 \%$ fertilizer)

interactions between microbes, organic matter, and fertilizer on power density (Table 8). Treatments with microbes and organic matter without fertilizer and $100 \%$ fertilizer significantly affected power density.

\section{Discussion}

The study was carried out in the rice field because the rice field has relatively constant nutrients and detrital sediments. Root exudates and detrital sediments can be used as sources of available nutrients for microbes. The rhizosphere is the best habitat for microbial growth because plant roots secreted root exudates. Organic compounds/molecules from root exudates, such as glucose, amino acids, organic acids, fatty acids and sterols, growth factors, nucleotides, can stimulate microbial growth. The MFC system can be applied to produce electric energy in the interface of water/sediment in the environment, such as the bay area, wetlands, and rice field (Figure 8). Electrical energy in the rice field can be generated as high as 80 $\mathrm{mW} / \mathrm{m}^{2}$ (based on the projected anode area) by this system. Microbes in the rhizosphere use organic exudates from rice roots to produce electricity (Nishio et al. 2010).

Table 5. The effect of treatment on electric current

\begin{tabular}{rlccccc}
\hline \multicolumn{1}{c}{ Pactor } & SS & V & MS & F & Sig \\
\hline Electric & Microbes & 4.408 & 1 & 4.408 & 2881.75 & $<0.000^{*}$ \\
current & Organic matter & 4.277 & 1 & 4.277 & 2795.79 & $<0.000^{*}$ \\
& Fertilizer & 0.166 & 2 & 0.083 & 54.328 & $<0.0001$ \\
& Int 1 (M*BO) & 3.091 & 1 & 3.091 & 2020.31 & $<0.0001$ \\
& Int 2 (M*K) & 0.178 & 2 & 0.089 & 58.337 & $<0.0001$ \\
& Int 3 (BO*K) & 0.072 & 2 & 0.036 & 23.391 & $<0.0001$ \\
& Int 4 (M*BO*K) & 0.061 & 2 & 0.031 & 20.002 & $<0.0001$ \\
\hline
\end{tabular}


Table 6. The effect of treatment combination (microbes, organic matter, and fertilizer) on electric current

\begin{tabular}{lccl}
\hline Microbes & Organic matter & Fertilizer & $\begin{array}{l}\text { Electric current } \\
(\boldsymbol{\mu A})\end{array}$ \\
\hline M0 & BO0 & K0 & $0.04 \pm 0.01 \mathrm{f}$ \\
M0 & BO0 & K1 & $0.13 \pm 0.01 \mathrm{e}$ \\
M0 & BO0 & K2 & $0.12 \pm 0.01 \mathrm{e}$ \\
M0 & BO1 & K0 & $0.16 \pm 0.04 \mathrm{de}$ \\
M0 & BO1 & K1 & $0.22 \pm 0.01 \mathrm{~d}$ \\
M0 & BO1 & K2 & $0.22 \pm 0.02 \mathrm{~d}$ \\
M1 & BO0 & K0 & $0.14 \pm 0.02 \mathrm{e}$ \\
M1 & BO0 & K1 & $0.35 \pm 0.03 \mathrm{c}$ \\
M1 & BO0 & K2 & $0.13 \pm 0.03 \mathrm{e}$ \\
M1 & BO1 & K0 & $1.63 \pm 0.1 \mathrm{a}$ \\
M1 & BO1 & K1 & $1.63 \pm 0.03 \mathrm{a}$ \\
M1 & BO1 & K2 & $1.2 \pm 0.06 \mathrm{~b}$ \\
\hline
\end{tabular}

Note: Values followed by a similar letter in the same column are significantly differed according to Duncan Multiple Range Test at $5 \%$ level
Table 8. The effect of treatment combination (microbes, organic matter, and fertilizer) on power density

\begin{tabular}{lccl}
\hline Microbes & Organic matter & Fertilizer & $\begin{array}{l}\text { Power Density } \\
\left(\mathbf{m W} / \mathbf{m}^{2}\right)\end{array}$ \\
\hline M0 & BO0 & K0 & $0.000 \pm 0.00002 \mathrm{e}$ \\
M0 & BO0 & K1 & $0.003 \pm 0.0002 \mathrm{e}$ \\
M0 & BO0 & K2 & $0.002 \pm 0.0002 \mathrm{e}$ \\
M0 & BO1 & K0 & $0.003 \pm 0.001 \mathrm{e}$ \\
M0 & BO1 & K1 & $0.006 \pm 0.003 \mathrm{e}$ \\
M0 & BO1 & K2 & $0.005 \pm 0.003 \mathrm{e}$ \\
M1 & BO0 & K0 & $0.006 \pm 0.001 \mathrm{e}$ \\
M1 & BO0 & K1 & $0.09 \pm 0.0009 \mathrm{~d}$ \\
M1 & BO0 & K2 & $0.006 \pm 0.0006 \mathrm{e}$ \\
M1 & BO1 & K0 & $0.09 \pm 0.01 \mathrm{a}$ \\
M1 & BO1 & K1 & $0.08 \pm 0.001 \mathrm{~b}$ \\
M1 & BO1 & K2 & $0.06 \pm 0.002 \mathrm{c}$ \\
\hline
\end{tabular}

Note: Values followed by a similar letter in the same column are significantly differed according to Duncan Multiple Range Test at $5 \%$ level

Table 7. The effect of treatment on power density

\begin{tabular}{rlccccc}
\hline \multicolumn{1}{r}{ P } & \multicolumn{1}{c}{ Factor } & SS & V & MS & F & Sig \\
\hline Electric & Microbes & 14838.488 & 1.00 & 14838.488 & 1271.24 & $0.000^{*}$ \\
current & Organic matter & 11560.550 & 1.00 & 11560.550 & 990.41 & $0.000^{*}$ \\
& Fertilizer & 360.371 & 2.00 & 180.186 & 15.43 & $0.000^{*}$ \\
& Int 1 $\left(\mathrm{M}^{*} \mathrm{BO}\right)$ & 9562.884 & 1.00 & 9562.884 & 819.271 & $0.000^{*}$ \\
& Int 2 $\left(\mathrm{M}^{* \mathrm{~K})}\right.$ & 420.154 & 2.00 & 210.077 & 17.998 & $0.000^{*}$ \\
& Int 3 $\left(\mathrm{BO}^{* \mathrm{~K})}\right.$ & 228.557 & 2.00 & 114.279 & 9.790 & $0.001^{*}$ \\
& Int 4 $\left(\mathrm{M}^{*} \mathrm{BO} * \mathrm{~K}\right)$ & 246.317 & 2.00 & 123.159 & 10.551 & $0.001^{*}$ \\
\hline
\end{tabular}

Note: *significance

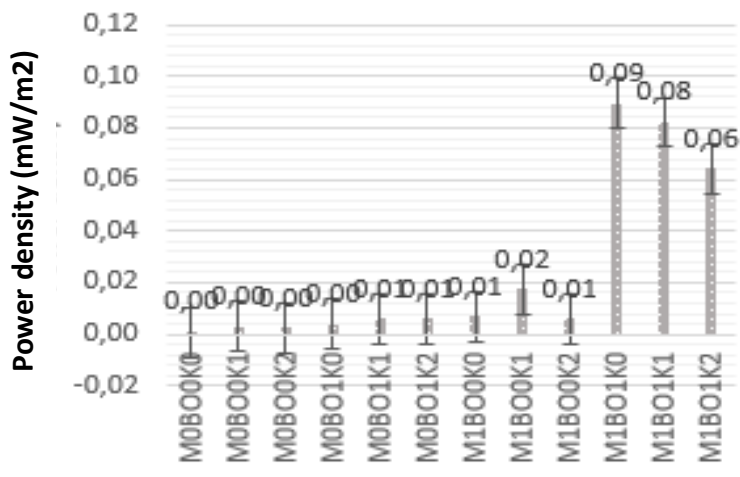

Treatments

Figure 7. Power density produced by treatment of (M0: without and $\mathrm{M} 1$ : with microbe), organic matter (BO0: without and $\mathrm{BO} 1$ : with organic matter), and fertilizer (K0: without, K1: $50 \%$ fertilizer, and K2: $100 \%$ fertilizer)

The result showed that MFC prototype no. 2 produced an electric voltage and an electric current higher than the others. The design of a prototype (MFC prototype that has square-shaped holes at the top and bottom of the pipe) causes electrons produced in the anode section to move

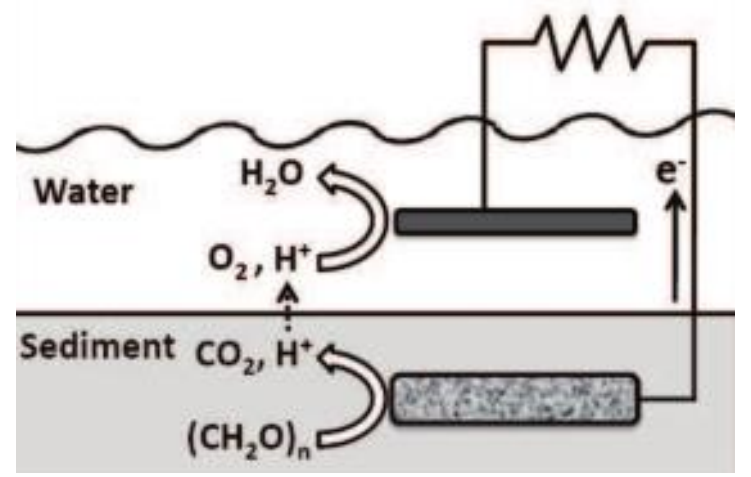

Figure 8. MFC on rice field (Nishio et al. 2010)

flexibly to the cathode section. Organic substrates (organic matter) are oxidized by microorganisms in the anode section and produce electrons, protons, and carbon dioxide. Electrons generated from the microbial metabolic activity are transferred to the surface of the anode by redox-active proteins or cytochromes and then forwarded to the cathode through an electrical circuit (Borole et al. 2011; Kumar et 
al. 2015). The next reaction is the reduction of electrons in the cathode section. Oxygen or ferricyanide provided at the cathode becomes the electron receiver, then the electron joins the protons and oxygen to form water.

The next research is to use the selected MFC prototype to find out the best treatment combination to produce electrical energy. The treatment of the addition of microbes, organic matter, and $50 \%$ fertilizer produced the electric Voltage of $555 \mathrm{mV}$ and an electric current of 1.63 $\mu \mathrm{A}$. According to Zheng et al. (2015), the Voltage generated by MFC in lowland rice was in the range of 500$708 \mathrm{mV}$. The results are similar to the research of Ganjar (2015) that a redox reaction in the soil is equal to $320-840$ $\mathrm{mV}$. The addition of microbes and organic matter significantly increased the electric Voltage (Table 2, 3, and 4). Organic matter supports microbial growth so that microbes can metabolize adequately and produce electrical Voltage. The application of fertilizer does not significantly affect the electric Voltage but increases the electric current generated by the MFC significantly. The use of $100 \%$ fertilizer produced lower electrical Voltage and electric current on MFC compared to the $50 \%$ fertilizer. It might be caused by increasing soil fertility and a good environment in the rhizosphere so that indigenous microbes populations increase and compete with microbial populations added from outside, causing excess nutrients resulting in the reduced microbial population. The lowered microbial community might influence the amount of electric current. Fertilizer residues can cause eutrophication. Fertilizers that contain substances such as nitrate and phosphate can be toxic to aquatic life. Fertilizer residue causes the overgrowth of algae in the water, so that decreases oxygen levels, and then results in a poisonous environment and endanger the life of aquatic fauna. This condition possibly occurs in the dominant anaerobic ecosystem in the rice fields.

Treatment interaction between microbes, organic matter, and fertilizer does not significantly affect electric Voltage generated by the MFC. The addition of microbes and organic matter with no fertilizer and 50\% fertilizer generated the highest electrical current of MFC. It is due to microbes play an important role in the anode space and the generation of electrons (Lovley 2006). The anaerobic anode chamber is one of the main parts of the MFC. All necessary conditions for the degradation of biomass are required in the anode chamber, i.e., the availability of substrates, mediators (optional), microbes, and electrodes as electron acceptors. Microbial groups that are generally used in MFCs are electric bacteria or fermentative bacteria.

The addition of organic matter results in a higher electrical voltage than those of organic matter. All treatments using organic matter showed good results. Microbes that can produce cellulase enzymes can decompose organic matter containing lignin and cellulose and produces glucose as energy for microbes.

In the electrical system, apart from electric Voltage, the electric current is also required to be able to calculate power density. Electric current is a flow that occurs due to the amount of electric charge flows from one point to another in a series of each unit of time. Electric current also occurs due to a potential difference or Voltage on the conducting medium between two points. The higher the voltage value between the two points, results in the higher the amount of the current flowing at the two points. Electric current flows from a positive charge to a negative charge, or it can also be interpreted that an electric current flows from a high potential to a low potential. Electrons transfer from the positive pole to the negative pole causes the lamp/light to turn on. The lamp or electric device will not be turned on if there is no electrical current. Electric current flowing in a series is important to determine; therefore, this study measures the electric current generated by the MFC prototype at each treatment.

The highest power density is generated from the treatment of the addition of microbes and organic matter with no fertilizer and $50 \%$ fertilizer. Treatment of the addition of microbes without the addition of organic matter showed insignificant results on power density although fertilizer was applied following the recommended dosage $(100 \%)$, even producing the lowest yield $(0.0009 \pm 0.0002$ $\mathrm{mW} / \mathrm{m}^{2)}$. It is due to the absence of microbes and organic matter as a food source for microbial metabolism. The interaction between the three factors is important to determine the relationship between microbial administration, organic matter, and fertilizer (Urea, SP-36, and $\mathrm{KCl}$ ). Microbes require organic matter as a substrate for metabolic processes and produce electrical energy. Based on the observations, there are interactions of power density which is almost the same as the electric current generated. The higher electrical power causes a higher electric current.

In conclusion, the MFC prototype number 2 (MFC prototype that has square-shaped holes at the top and bottom of the pipe) was the best Microbial Fuel Cell (MFC) prototype among three MFC prototypes; it produced the highest electric Voltage. The addition of microbes and organic matter increases the Voltage generated by the MFC. Microbes can decompose organic matter and use for metabolism and produce electrical energy. Application of microbes, organic matter, and without fertilizer (Urea, SP-36, and $\mathrm{KCl}$ ) and fertilizer at a dose of $50 \%$ recommended dosage results in the highest electric current and electric power. The highest electrical Voltage $(555 \mathrm{mV})$ was resulted in the treatment of the addition of microbes and organic matter, without fertilizer. The highest electrical current $(1.63 \mu \mathrm{A})$ was produced at the treatments of the addition of microbes, organic matter, without and with $50 \%$ fertilization. The highest power density $\left(0.09 \mathrm{~mW} / \mathrm{m}^{2}\right)$ was generated by the treatment of the addition of microbes and organic matter, without fertilization

\section{ACKNOWLEDGEMENTS}

We would like to thank the Indonesian Center for Biodiversity and Biotechnology (ICBB) Bogor for funding and supporting the research. 


\section{REFERENCES}

Borole AP, Reguera G, Ringeisen B, Wang ZW, Feng Y, Kim BH. 2011 Electroactive biofilms: Current status and future research needs. Energy Environ Sci 4 (12): 4813-4834. DOI: 10.1039/ C1EE02511B.

Fan LP, Xue S. 2016. Overview on electricigens for Microbial Fuel Cell. Open Biol 10: 398-406. DOI: 10.2174/1874070701610010398.

Ganjar A. 2015. Studi Faktor Penyebab Kerusakan Tanah di DaerahAliran Sungai Bomo Kabupaten Banyuwangi. [Hon. Thesis]. Universitas Jember, Jawa Timur. [Indonesian]

Guerrero-Ranger N. 2010. Comparative study of three cathodic electron acceptors on the performance of Microbial Fuel Cell. Electron Power Eng 4 (1): 27-31.

He Z, Wagner N, Minteer SD, Angenent LT. 2006. The upflow microbial fuel cell with an interior cathode: Assessment of the internal resistance by impedance spectroscopy. Environ Sci Technol 40: 5212 5217. DOI: 10.1021/es060394f.

Indriyani YA. 2017. Eksplorasi, Seleksi, dan Identifikasi Mikrob Electricigens dari Ekosistem di Indonesia untuk Microbial Fuel Cell (MFC). [Thesis]. Institut Pertanian Bogor, Jawa Barat. [Indonesian]

Kumar R, Singh L, Wahid ZA. 2016. Exoelectrogens: Recent advances in molecular drivers involved in extracellular electron transfer and strategies used to improve it for microbial fuel cell applications. Renew Sustain Energy Rev 56: 1322-1336. DOI: 10.1016/j.rser.2015.12.029.

Liu H, Cheng S, Logan BE. 2005. Power generation in fed-batch microbial fuel fell as a function of ionic strength, temperature, and reactor configuration. J Environ Sci Technol 39 (14): 5488-5493. DOI: $10.1021 / \mathrm{es} 050316 \mathrm{c}$.
Liu H, Ramnarayanan R, Logan BE. 2004. Production of electricity during wastewater using a single-chamber microbial fuel cell. J Environ Sci Technol 38 (7): 2281-2285. DOI: 10.1021/es034923g.

Logan BE, Murano C, Scott K, Gray ND, Head IM. 2005. Electricity generation from L-cysteine in microbial fuel cell. Water Res 39 (5): 945-952. DOI: 10.1016/j.watres.2004.11.019.

Lovley DR, Nevin KP. 2008. Chapter 23: Electricity production with electricigens. In: Wall JD, Harwood CS, Demain A (eds). Bioenergy. ASM Press, Washington. DC.

Min B, Cheng S, Logan BE. 2005. Electricity generation using membrane and salt bridge microbial fuel cell. Water Res 39: 1675-1686. DOI: 10.1016/j.watres.2005.02.002.

Min B, Roman OB, Angelidaki I. 2008. Importance of temperature and anodic medium composition on microbial fuel cell (MFC) performance. Biotechnol Lett 30 (7): 1213-1218. DOI: 10.1007/s10529-008-9687-4.

Nishio K, Hashimoto K, Watanabe K. 2010. Light/electricity conversion by a selforganized photosynthetic biofilm in a single-chamber reactor. Appl Microbiol Biotechnol 86 (3): 957-964. DOI: 10.1007/s00253009-2400-2.

Sun M, Reible DD, Lowry GV, Gregory KB. 2012. Effect of applied voltage, initial concentration, and natural organic matter on sequential reduction/oxidation of nitrobenzene by graphite electrodes. Environ Sci Technol 46: 6174-6181. DOI: 10.1021/es300048y.

Zheng C, Wang N, Li H, Su J, Zhao F. 2015. Bacterial community composition at anodes of microbial fuel cells for paddy soils: The effects of soil properties. J Soils Sediments 15: 926-936. DOI: 10.1007/s11368-014-1056-4. 